\title{
Think before throwing away the amputated part!
}

\author{
Smriti Bhushan, Ritesh Bazaz, Ravikiran Naalla, ${ }^{\circledR}$ Maneesh Singhal
}

Plastic Reconstructive \& Burns Surgery, All India Institute of Medical Sciences, New Delhi, India

\section{Correspondence to} Dr Ravikiran Naalla, ravi_2488@yahoo.co.in

Accepted 22 April 2019

\section{DESCRIPTION}

A 18-year-old man presented to us following a sideswipe injury leading to crush avulsion amputation of the right upper limb at the level of the upper $1 / 3$ of the humerus shaft. The injury occurred 7 hours earlier, and he was haemodynamically stable at the time of presentation. On examination of the amputated distal stump, we noticed multisegmental both bone open fractures and extensive crush injury of the forearm muscles. The skin over the proximal stump was gangrenous; the arm muscles were crushed and contaminated (figure 1). Because of the severity of the injury and late presentation, replantation of the upper limb was deferred, and free fillet flap was planned. Though the ischaemia time in our patient was 7 hours, we believe that a skin flap from the amputated limb can be used if the maximal duration of ischaemia is up to 12 hours in an unpreserved and up to 24 hours in a well-preserved amputated part.
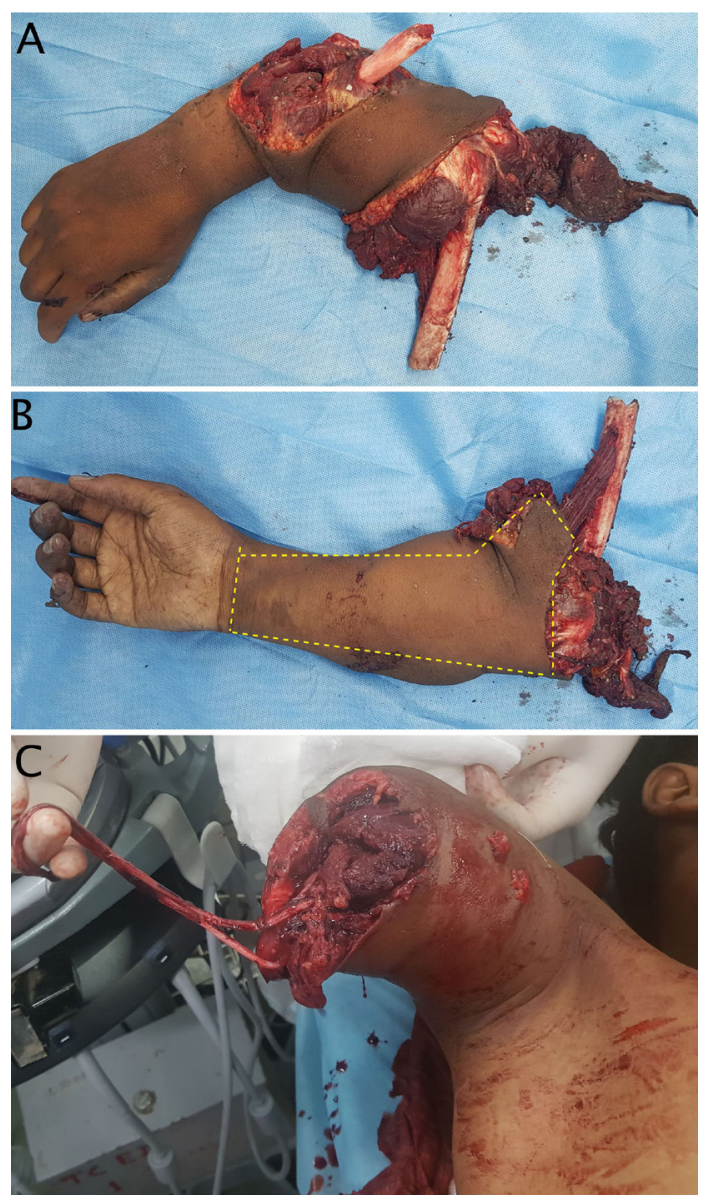

Figure 1 Image showing (A) dorsal and (B) volar surface of amputated right upper limb and (C) proximal arm stump.

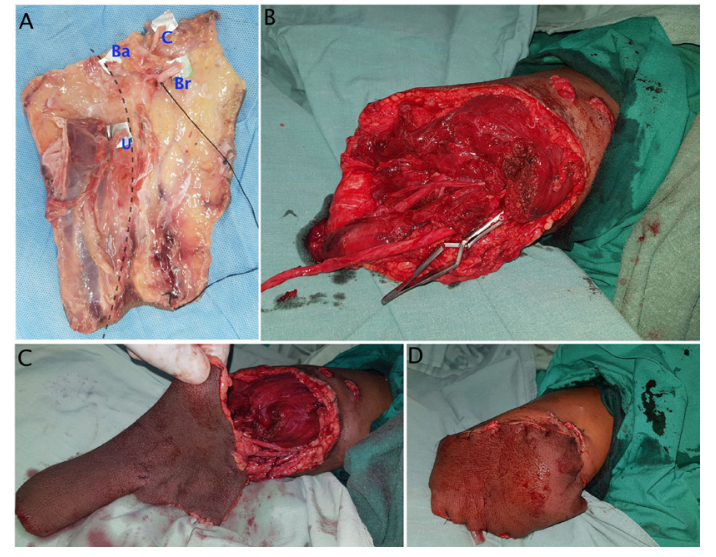

Figure 2 Image showing (A) forearm fillet flap, the longitudinal curved dotted line divides the flap arbitrarily into ulnar and radial forearm flaps. The ulnar forearm flap was discarded. (B) Proximal arm stump after debridement, (C) end-to-end anastomosis between brachial artery, cephalic and basilic veins and (D) after flap inset. Ba, basilic vein; Br, brachial artery; C, cephalic vein; U, ulnar vessels.

Meanwhile, we had covered the amputated part with moist gauze and placed it in a plastic bag. This bag was put in another plastic bag filled with ice and water. In this manner, the amputated part was preserved and taken to the operation theatre. The part was scrubbed with diluted $4 \%$ chlorhexidine gluconate solution and rinsed with copious amount of normal saline to clear the debris. The remaining

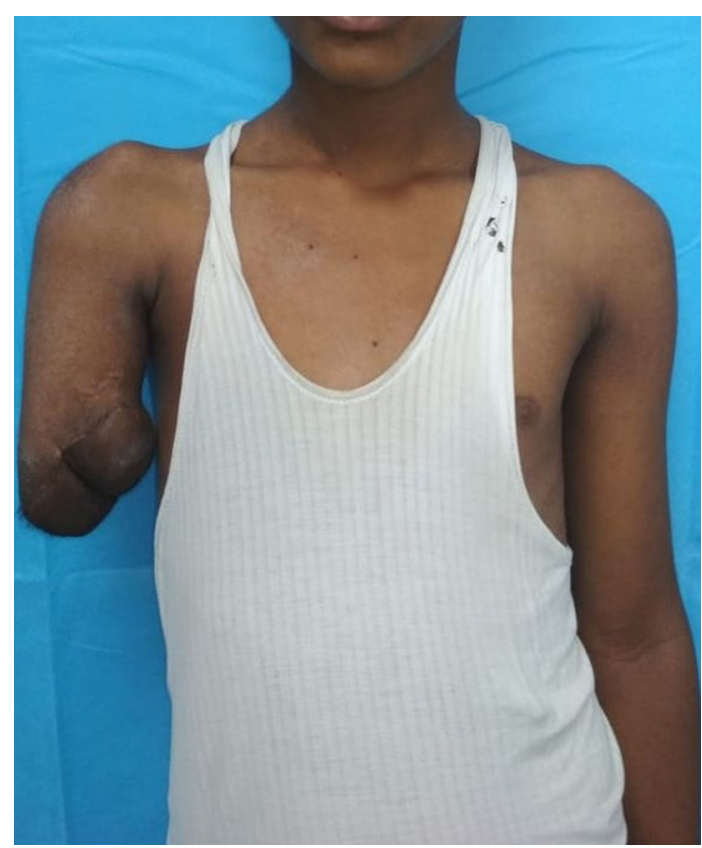

Figure 3 Image showing well-settled flap. 
debris was removed surgically under loupe magnification. In our practice, we do not flush the vessels with iced Ringers solution, heparinised saline solution or any special solution.

A conjoined radial and ulnar artery forearm flap was harvested from the amputated forearm as we had a suspicion either of them would have been damaged in the crush injury. Both radial and ulnar vessels were uninjured. The gangrenous skin and contaminated arm muscles were debrided, and brachial artery, basilic vein and cephalic vein were tagged for anastomosis. Ulnar vessels were ligated and divided at their origin; ulnar portion of the conjoined flap was discarded. The free forearm fillet flap was based on the brachial artery in continuity with the radial artery, cephalic vein and basilic vein. An end-to-end anastomosis

\section{Patient's perspective}

'It is very unfortunate to lose an upper limb, I'm somewhat comforted by the fact that something could be used from the amputated part.'

\section{Learning points}

- While a decision to replant or use parts of it as a free flap, the amputated limb needs to be preserved. It has to be covered with moist gauze and placed in a plastic bag. This bag has to be put in another container filled with ice and water.

- Soft tissue defects of upper limb following trauma can be reconstructed by tissue harvested from a non-salvageable amputated part.

- Fillet flap can provide stable soft tissue cover for complex amputated stump wounds. was performed between the two ends of brachial artery with 8-0 prolene sutures. Similarly, the basilic vein and cephalic vein were anastomosed (figure 2). Postoperatively, enoxaparin sodium $(1 \mathrm{mg} / \mathrm{kg} /$ day) was used as an anticoagulant for 5 days. The patient had an uneventful recovery with stable soft tissue cover over the arm stump (figure 3). We referred him for a prosthesis.

Fillet flap is a type of axial pattern flap that can be used as a pedicle flap and free flap. ${ }^{1}$ This belongs to the concept of 'spare parts' in which the tissues are harvested from the non-salvageable amputated parts to be used at the site of the proximal stump. Fillet flaps are traditionally used to resurface large traumatic and oncological soft tissue defects. ${ }^{2}$ In either scenario, a large amount of tissue can be harvested from the non-salvageable portion to cover the soft tissue defects. By this procedure, donor site morbidity of other regions can be avoided. In our patients, there was skin and soft tissue deficit following the debridement of the arm stump. Primary closure of the wound would result in undue shortening of the stump. Skin grafting is an alternate option, but it would result in a suboptimal soft tissue cover. In this way, a free fillet flap provided stable soft tissue cover and a more usable stump.

Contributors $\mathrm{SB}$ and $\mathrm{RB}$ are involved in patient care. $\mathrm{RN}$ is the operating surgeon and involved in article write up. MS is the guide and professor incharge.

Funding The authors have not declared a specific grant for this research from any funding agency in the public, commercial or not-for-profit sectors.

Competing interests None declared.

Patient consent for publication Obtained.

Provenance and peer review Not commissioned; externally peer reviewed.

\section{REFERENCES}

1 Ver Halen JP, Yu P, Skoracki RJ, et al. Reconstruction of massive oncologic defects using free fillet flaps. Plast Reconstr Surg 2010;125:913-22.

2 Küntscher MV, Erdmann D, Homann HH, et al. The concept of fillet flaps: classification, indications, and analysis of their clinical value. Plast Reconstr Surg 2001;108:885-96.

Copyright 2019 BMJ Publishing Group. All rights reserved. For permission to reuse any of this content visit

https://www.bmj.com/company/products-services/rights-and-licensing/permissions/

BMJ Case Report Fellows may re-use this article for personal use and teaching without any further permission.

Become a Fellow of BMJ Case Reports today and you can:

- Submit as many cases as you like

- Enjoy fast sympathetic peer review and rapid publication of accepted articles

- Access all the published articles

Re-use any of the published material for personal use and teaching without further permission

For information on Institutional Fellowships contact consortiasales@bmjgroup.com

Visit casereports.bmj.com for more articles like this and to become a Fellow 